\title{
Pengembangan Keterampilan Berpikir Tingkat Tinggi Melalui Pendekatan Open-Ended
}

\author{
I Wayan Januariawan', I Komang Wisnu Budi Wijaya², Ni Kadek Supadmini", \\ Diah Nirmala Dewi ${ }^{4}$ \\ 1SMK Negeri 3 Bangli \\ 234Universitas Hindu Negeri I Gusti Bagus Sugriwa Denpasar \\ 1add.janu@gmail.com, ${ }^{2}$ wisnu.budiwijaya240191@gmail.com \\ 3ayutrisnadewimaheswari@gmail.com, 4nluthey39@yahoo.com
}

DOI : $10.37329 /$ cetta.v3i2.444

\begin{tabular}{ll}
\hline Keywords: & \\
\hline High & order \\
thinking & skills; \\
open-ended & \\
approach & \\
\hline
\end{tabular}

Abstract
Nowadays industrial revolution era, High Order Thinking Skills
(HOTS) is part of skills needed to face global rivalry and complex life
challenges. However, these skills incline to be little-mastered. It seems
to be necessary to develop Higher Order Thinking Skills from the early-
ages, especially for students which are integrated in the learning
process. This study is a kind oflibrary research. The result of this study
showed is the advancement of HOTS can be done through an open-
ended approach. The open-ended approach is able to stimulate the
students in getting used to think critically, logically, creatively,
collusively, argumentating, until decision making in the form of
problem solving which contains analyzing, evaluating, and creating
activities. Thus, the open-ended approach is well done in the learning
process that can support the development of Higher Order Thinking
Skills (HOTS)

\section{Kata kunci:}

Keterampilan berpikir tingkat tinggi, pendekatan openended.

\begin{abstract}
Abstrak
Di era revolusi industri sekarang ini, High Order Thinking Skills (HOTS) merupakan bagian dari keterampilan yang diperlukan dalam menghadapi persaingan global dan tantangan kehidupan yang semakin kompleks. Akan tetapi, penguasaan terhadap keterampilan tersebut masih tergolong rendah. Oleh karena itu diperlukan pengembangan keterampilan berpikir tingkat tinggi mulai sejak dini khususnya kepada para siswa yang terintegrasi dalam proses pembelajaran. Penelitian ini digolongkan dalam studi kepustakaan. Hasil penelitian menyatakan bahwa pengembangan keterampilan berpikir tingkat tinggi dapat dilakukan melalui pendekatan open-ended. Pendekatan open-ended merangsang siswa untuk melatih dan membiasakan diri dalam berpikir kritis, logis, kreatif, pemecahan masalah, kemampuan beragumen sampai pada
\end{abstract}


pengambilan keputusan berupa penyelesaian masalah yang melibatkan aktivitas menganalisis, mengevaluasi, dan menciptakan. Dengan demikian pendekatan open-ended sangat baik dilakukan dalam proses pembelajaran yang dapat menunjang berkembangnya keterampilan berpikir tingkat tinggi (HOTS)

\section{Pendahuluan}

Saat ini dunia tengah dihadapkan pada sebuah era yang dikenal dengan era Revolusi Industri 4.0 (Wijaya, 2020). Di era sekarang ini, masyarakat dunia dihadapkan dengan begitu pesatnya perubahan yang terjadi di berbagai sektor bidang baik itu bidang pendidikan, industri, komunikasi dan informasi, sosial dan budaya. Perubahan ini memunculkan berbagai pengaruh dan tantangan yang harus disikapi dengan bijak dan menuntut para masyarakat dunia untuk segera berupaya menyesuaikan dengan perubahan tersebut. Agar mampu bertahan dalam derasnya arus perubahan global, penguasaan keterampilan yang relevan dengan era ini sangat diperlukan.

Generasi muda khususnya para siswa, hendaknya mulai dibiasakan untuk dilatih dan dikembangkan berbagai keterampilan yang diperlukan dalam menghadapi daya saing global. Keterampilan tersebut harus mulai diintegrasikan dalam proses pembelajaran. Salah satu keterampilan yang diperlukan atau dibutuhkan oleh seseorang agar berhasil menghadapi tantangan, tuntutan kehidupan yang semakin kompleks dan berhasil dalam bersaing secara global, hidup serta karir di dunia kerja yakni keterampilan berpikir tingkat tinggi atau High Order Thinking Skills (HOTS).

High Order Thingking Skills (HOTS) merupakan keterampilan atau kemampuan yang melibatkan proses berpikir untuk menghubungkan, memanipulasi, dan mengubah pengetahuan serta pengalaman yang telah dimiliki secara kritis kreatif dalam menentukan keputusan untuk menyelesaikan suatu permasalahan (Dinni, 2018). King, Goodson, \& Rohani (2012) memaparkan bahwa yang termasuk ke dalam kemampuan atau keterampilan berpikir tingkat tinggi (HOTS) antara lain kemampuan berpikir kritis, logis, reflektif, metakognitif dan kreatif. Keterampilan berpikir tingkat tinggi bertujuan untuk meningkatkan kemampuan berpikir siswa pada tingkat yang lebih tinggi, terutama yang meliputi kemampuan untuk berpikir secara kritis, kreatif dalam memecahkan suatu masalah, serta membuat keputusan dalam berbagai situasi atau kondisi yang kompleks . 
Hasil penelitian Meika \& Sujana (2017) menunjukkan bahwa kemampuan berpikir kreatif dan pemecahan masalah matematis siswa belum optimal atau masih sangat rendah. Selain itu, PISA (Program for International Student Assessment) dan TIMSS (Trends in International Mathematics and Science Study) juga melaporkan bahwa peserta Indonesia hanya mampu mencapai tingkatan kedua dari enam tingkatan berpikir pada soal yang dikompetisikan. Hal ini memperlihatkan bahwa kemampuan siswa untuk berpikir logis, kritis dan rasional masih tergolong rendah (Sani, 2016). Rendahnya kemampuan berpikir tersebut terjadi karena para siswa belum terbiasa atau terlatih untuk dihadapkan dengan proses pembelajaran yang mengiring kepada suatu permasalahan yang dapat dipecahkan dengan berbagai solusi atau pola pikir divergen. Selain itu, siswa juga seringkali sulit untuk mengembangkan ide atau gagasannya dan cenderung terpaku pada alternatif pemecahan masalah yang sama. Oleh karena itu, diperlukan pengembangan keterampilan berpikir tingkat tinggi atau High Order Thinking Skills dalam proses pembelajaran guna melatih dan membiasakan siswa untuk berpikir kritis, kreatif, pemecahan masalah dan logis.

Salah satu upaya yang dapat dilakukan untuk mengembangkan kemampuan berpikir tingkat tinggi dalam proses pembelajaran adalah dengan menggunakan pendekatan open-ended. Pendekatan open-ended merupakan pendekatan dalam pembelajaran yang dapat memberikan kebebasan kepada siswa dalam menyelesaikan masalah dalam pembelajaran. Hal tersebut dikarenakan siswa diberikan kesempatan untuk menginvestigasi berbagai strategi yang diyakininya sesuai dengan kemampuan mengelaborasi, sehingga kemampuan berpikir siswa dapat berkembang secara maksimal dan kegiatan-kegiatan kreatif dari setiap siswa terkomunikasikan melalui proses belajar mengajar (Muhsinin, 2013). Sari, Wahyuni, \& Rosmaiyadi (2016) menyatakan bahwa penggunaan pendekatan pembelajaran open-ended dirasakan efektif dalam meningkatan keaktifan belajar siswa, karena siswa akan terlatih untuk mengemukakan gagasan secara kreatif dan kritis, serta terlatih menggunakan kemampuan analitis dan imajinatif dalam dirinya untuk menghadapi berbagai persoalan yang ada. Beberapa hasil penelitian menunjukkan bahwa penggunaan pendekatan pembelajaran dengan open-ended berpengaruh signifikan terhadap peningkatan kemampuan berpikir kreatif, penalaran dan pemecahan masalah (Lahra, Hasan, \& Mursal, 2017; Lestari, Hartono, \& Purwoko, 2016; Suwandi, Hasnunidah, \& Marpaung, 2016). 
Mencermati dari berbagai aspek yang menjadi bagian dari keterampilan berpikir tingkat tinggi, pembelajaran dengan pendekatan open-ended relevan untuk pengembangan keterampilan berpikir tingkat tinggi atau High Order Thinking Skills. Hal itu disebabkan karena setiap prinsip, aspek dan tahapan dari pendekatan open-ended memiliki keterkaitan yang erat dengan keterampilan berpikir tingkat tinggi. Melalui pendekatan open-ended, keterampilan High Order Thinking yang meliputi berpikir kritis, kreatif, pemecahan masalah, kemampuan beraguman dan pengambilan keputusan dapat diintegrasikan dalam proses pembelajaran.

\section{Metode}

Penelitian ini digolongkan ke dalam penelitian studi kepustakaan. Studi kepustakaan merupakan studi yang dilakukan oleh penulis untuk mencari dasar pijakan serta memperoleh dan membangun landasan teori, kerangka berpikir dan menentukan dugaan sementara (Darmadi, 2011). Berbagai jurnal ilmiah serta sumber lainnya dieksplorasi sebagai dasar dalam menyusun artikel ini. Sumber tersebut kemudian ditelaah serta dianalisis menggunakan teknik analisis isi atau analisis ilmiah terhadap isi suatu pesan atau literatur (Supadmini, Wijaya, \& Larashanti, 2020).

\section{Pembahasan}

\section{Keterampilan Berpikir Tingkat Tinggi (High Order Thinking Skills)}

Kemampuan berpikir merupakan kemampuan dalam mengkonstruksi informasi, pengetahuan dan pengalaman secara kognitif yang dimulai dari tingkat rendah hingga tingkat tinggi. Berdasarkan tingkatan proses berpikir, kemampuan berpikir dibagi menjadi dua yakni kemampuan berpikir tingkat rendah atau Lower Order Thinking Skills (LOTS) dan kemampuan berpikir tingkat tinggi atau High Order Thinking Skills (HOTS) (Badjeger \& Purwaningrum, 2018). Menurut Ariandari (2015), kemampuan berpikir tingkat rendah (LOTS) merupakan kemampuan yang terbatas pada hal-hal rutin dan bersifat mekanis, seperti menghafal dan mengulang-ulang informasi sebelumnya. Sementara, kemampuan berpikir tingkat tinggi (HOTS) merupakan kemampuan yang dapat merangsang siswa untuk mengintrepretasikan, menganalisa atau bahkan mampu memanipulasi informasi yang sudah diperoleh sebelumnya sehingga tidak monoton. 
Keterampilan berpikir tingkat tinggi atau High Order Thinking Skills merupakan keterampilan yang mengarahkan seseorang untuk mengaplikasikan informasi baru atau pengetahuan yang sudah dimiliki sebelumnya dan memanipulasi informasi tersebut untuk memunculkan solusi penyelesaian atau jawaban dalam situasi yang baru (Heong, et al., 2011). Dinni (2018) menyebutkan bahwa keterampilan berpikir tingkat tinggi meliputi kemampuan pemecahan masalah (problem solving), kemampuan berpikir kreatif (creative), berpikir kritis (critical thinking), kemampuan berargumen, dan kemampuan mengambil keputusan. Sementara itu, menurut Brookhart (2010) keterampilan High Order Thinking merupakan keterampilan berpikir yang terdiri atas kemampuan logika dan penalaran (logic and reasoning), analisis (analysis), evaluasi (evaluation), dan kreasi (creation), pemecahan masalah, dan pengambilan keputusan.

Konsep dari HOTS didasari oleh beberapa pendapat seperti Krulik \& Rudnick (1999), Taksonomi kognitif bloom dan taksonomi bloom revisi Anderson \& Krathwohl (2001). Krulik \& Rudnick (1999) (dalam Ariandari, 2015) menyatakan bahwa keterampilan berpikir dibagi menjadi empat tingkat, dimulai dari menghafal (recall thinking), dasar (basic thinking), hingga kemampuan berpikir kritis (critical thinking) dan kreatif (creative thinking). Recall thinking dan basic thinking merupakan keterampilan berpikir yang tergolong Lower Order Thinking karena masih didasarkan atas pengetahuan yang berdasarkan ingatan dan pemahaman yang berangsung secara otomatis dan reflektif. Sedangkan untuk keterampilan berpikir kritis dan kreatif melibatkan kemampuan analisis, menghubungkan, memanipulasi informasi untuk menghasilkan berbagai alternatif atau solusi (creative thinking) dalam proses memecahkan permasalahan yang ditemukan. Berdasarkan taksonomi Bloom, keterampilan berpikir disusun secara hirarki yang terdiri dari enam level yakni pengetahuan (knowledge), pemahaman (comprehension), pengaplikasian (application), analisis (analysis), sintesis (synthesis), dan evaluasi (evaluation). Anderson \& Krathwohl, (2001) selanjutnya mengembangkan taksonomi Bloom menjadi mengingat (remember), memahami (understand), mengaplikasikan (apply), menganalisis (analyze), mengevaluasi (evaluate) dan menciptakan (create). Keterampilan mengingat, memahami dan mengaplikasikan merupakan keterampilan yang tergolong dalam recalling, sedangkan mengevaluasi termasuk kedalam kemampuan berpikir kritis dan menciptakan termasuk kedalam berpikir kreatif. Proses Kognitif sesuai dengan level kognitif Bloom disajikan dalam tabel berikut. 
Tabel 1 Proses Kognitif sesuai dengan level kognitif Bloom

\begin{tabular}{|c|c|c|c|}
\hline \multicolumn{3}{|r|}{ Proses Kognitif } & Definisi \\
\hline \multirow{3}{*}{ LOTS } & $\mathrm{C} 1$ & Mengingat & $\begin{array}{l}\text { Mengambil pengetahuan yang } \\
\text { relevan dari ingatan. }\end{array}$ \\
\hline & $\mathrm{C} 2$ & Memahami & $\begin{array}{l}\text { Membangun arti dari proses } \\
\text { pembelajaran, } \\
\begin{array}{l}\text { termasuk } \\
\text { komunikasi lisan, tertulis, dan } \\
\text { gambar. }\end{array}\end{array}$ \\
\hline & $\mathrm{C} 3$ & Menerapkan/mengaplikasikan & $\begin{array}{l}\text { Melakukan atau menggunakan } \\
\text { prosedur di dalam situasi yang } \\
\text { tidak biasa. }\end{array}$ \\
\hline \multirow{3}{*}{ HOTS } & $\mathrm{C} 4$ & Menganalisis & $\begin{array}{l}\text { Memecah materi ke dalam bagian- } \\
\text { bagiannya dan menentukan } \\
\text { bagaimana bagian-bagian itu } \\
\text { terhubungkan antarbagian dan ke } \\
\text { struktur atau tujuan keseluruhan. }\end{array}$ \\
\hline & C5 & Menilai/mengevaluasi & $\begin{array}{l}\text { Membuat pertimbangan } \\
\text { berdasarkan kriteria atau standar. }\end{array}$ \\
\hline & C6 & Mengkreasi/mencipta & $\begin{array}{l}\text { Menempatkan unsur-unsur secara } \\
\text { bersama-sama untuk membentuk } \\
\text { keseluruhan secara koheren atau } \\
\text { fungsional; menyusun kembali } \\
\text { unsur-unsur ke dalam pola atau } \\
\text { struktur baru. }\end{array}$ \\
\hline
\end{tabular}

(Sumber: Ariyana, Pudjiastuti, Bestary, \& Zamroni, 2018)

Mengatur dan memotivasi siswa untuk berpikir tingkat tinggi dalam proses pembelajaran sangat penting dilakukan oleh guru. Menurut Conklin \& Manfro (2010) terdapat beberapa langkah yang dapat dilakukan oleh guru untuk memovitasi siswa untuk bepikir HOTS di kelas antara lain:

a. Menyajikan permasalahan atau pertanyaan-pertanyaan HOTS pada awal pelajaran untuk mengawali diskusi dan debat.

b. Mengajukan pertanyaan-pertanyaan HOTS pada akhir proses pembelajaran yang digunakan sebagai alat penilaian.

c. Pada pertengahan pelajaran dilakukan aktivitas brainstorming guna mendorong siswa menemukan dan mengembangkan ide sebagai wujud berpikir kreatif.

d. Memberikan tugas ataupun pekerjaan rumah yang berbasis open ended untuk mengetahui kreativitas dan pemahaman siswa terhadap pelajaran yang telah dipelajari. 


\section{Pendekatan Open-Ended}

Menurut Septiani \& Zanthy (2019), pendekatan Open-Ended merupakan pendekatan dalam pembelajaran yang memunculkan suatu permasalahan dengan metode penyelesaian yang lebih dari satu, sehingga dapat memberi kesempatan yang luas kepada siswa untuk memperoleh pengetahuan dan pengalaman untuk merumuskan, mengenali, serta memecahkan masalah dengan menggunakan lebih dari satu metode pemecahan masalah. Dengan kata lain, pendekatan open-ended mengarahkan siswa untuk membuka pikiran atau mengembangkan kemampuan berpikirnya secara leluasa dan terbuka guna mengkritisi, menganalisis dan mengevaluasi suatu permasalahan untuk menciptakan atau menghasilkan berbagai ide, gagasan, solusi atau alternatif penyelesaian melalui informasi, pengetahuan dan pengalaman yang dimiliki hingga sampai pada pengambilan keputusan (decision making)

Pada pendekatan open-ended, siswa dihadapkan dengan permasalahan yang bersifat terbuka, yaitu permasalahan yang diformulasikan memiliki multi answer (banyak penyelesaian) yang benar. Pembelajaran dengan open-ended membuat proses belajar mengajar akan menjadi lebih bersifat student oriented. Siswa mendapat kesempatan untuk menginvestigasi berbagai strategi dan cara yang diyakininya dan hal tersebut akan membuat siswa mendapat kesempatan untuk mengekspresikan ideidenya (Ariani, Candiasa, \& Marhaeni, 2014). Pendekatan open-ended dapat menunjang dan menfasilitasi siswa dalam mengembangkan dan meningkatkan keterampilan atau kemampuan berpikirnya. Pendekatan yang berorientasi pada pemberian masalah terbuka dapat mengembangkan dan meningkatkan pemahaman siswa, keterampilan berpikir kritis serta kreatif (Soeyono , 2014).

Tipe masalah open-ended yang dapat diberikan kepada siswa bersifat terbuka. Dasar keterbukaanya (openness) dapat dijabarkan kedalam tiga tipe masalah, yaitu : Process is open (proses secara terbuka), end product are open (produk akhir yang terbuka) dan ways to develop are open (pengembangan lanjutan yang terbuka). Proses yang terbuka dimaksudkan bahwa tipe permasalahan yang diberikan mempunyai banyak cara atau alternatif penyelesaian. Produk atau hasil akhir terbuka mengacu pada tipe permasalahan yang memiliki jawaban benar yang banyak (multiple), sedangkan cara pengembang lanjutannya terbuka, siswa dapat mengembangkan masalah baru dengan 
mengubah kondisi dari masalah sebelumnya (Lestari, Hartono, \& Purwoko, 2016). Lestari, Hartono, \& Purwoko (2016) menyebutkan bahwa terdapat beberapa langkahlangkah dalam pendekatan open-ended diantaranya:

a. Orientasi.

Pembelajaran diawali dengan penyampaian tujuan pembelajaran, pemberian motivasi dan apersepsi kepada siswa berupa masalah yang bersifat kontekstual.

b. Penyajian masalah terbuka.

Guru memberikan masalah secara umum tentang materi yang akan diberikan.

c. Pengerjaan masalah terbuka secara individu.

Siswa diminta menyelesaikan permasalahan secara individu untuk mengetahui perkembangan tingkat kreativitas siswa. Pada saat siswa mengerjakan masalahnya atau soal yang diberikan, siswa tidak diperbolehkan untuk minta bantuan kepada teman yang lain. Hal ini dimaksudkan agar siswa benar-benar terpacu kreativitasnya untuk menyelesaikan permasalahannya sendiri. Apabila telah selesai mengerjakannya, siswa diminta untuk mengumpulkan lembar penyelesaiannya.

d. Diskusi kelompok tentang masalah terbuka.

Pada tahap ini siswa akan diarahkan untuk berakivitas secara berkelompok guna mendiskusikan penyelesaian dari masalah open-ended yang telah dikerjakan secara individu. Melalui hal tersebut diharapkan dapat memunculkan ide pada tiap siswa sehingga nantinya kreativitas siswa akan meningkat.

e. Persentasi hasil diskusi kelompok.

Pada tahap ini, perwakilan atau semua anggota kelompok mempresentasikan hasil kerja mereka.

f. Penutup.

Siswa bersama guru menyimpulkan atau membuat ringkasan singkat tentang konsep atau ide yang terdapat pada permasalahan yang diajukan.

Dari langkah-langkah pendekatan open-ended yang dipaparkan di atas, menunjukkan bahwa dari awal pembelajaran siswa telah diarahkan untuk mulai berpikir analisis berbagai aspek dari sebuah permasalahan yang dimunculkan diawal, yang selanjutnya siswa akan mengevaluasi permasalahan tersebut hingga menghasilkan ide-ide atau gagasan sebagai bentuk kreativitas berpikir siswa berupa solusi atau pemecahan masalah. 
Hasil penelitian Biliya A, (2015) menunjukkan pendekatan open-ended berhasil dalam meningkatkan keterampilan proses dan hasil beljar siswa. Pendekatan open-ended dikatakan ampuh dalam meningkatkan keterampilan proses yang mencakup peningkatan keaktifan dan kemampuan siswa dalam aspek menganalisis yang meliputi mengamati, mengidentifikasi dan menghubungkan informasi guna memecahkan permasalahan, siswa diberikan ruang dalam mengasosiasi pengetahuan dan pengalaman yang dimiliki sehingga mampu mengambil keputusan (menyimpulkan) untuk pemecahan masalah, serta siswa menjadi terlatih dalam mengkomunikasikan ideide atau gagasan mereka.

\section{Pengembangan Keterampilan Berpikir Tingkat Tinggi Melalui Pendekatan Open-}

\section{Ended}

Pendekatan open-ended mengajak siswa untuk berpikir lebih kritis, imajinatif, konstruktif dalam memecahkan permasalahan. Tahapan pembelajaran dengan pendekatan open-ended yang mulai dari orientasi pembelajaran (preparation), penyajian masalah, pemecahan masalah secara individu maupun kelompok, dan mengkomunikasikan merupakan tahapan yang dapat menunjang berkembangnya kemampuan berpikir tingkat tinggi atau High Order Thinking Skills. Pengembangan keterampilan berpikir tingkat tinggi dalam pembelajaran open-ended dapat dilihat pada Tabel 2.

Tabel 2. Pengembangan keterampilan berpikir tingkat tinggi dalam pembelajaran openended

\begin{tabular}{|c|c|c|c|c|}
\hline $\begin{array}{c}\text { Tahapan } \\
\text { Open- } \\
\text { Ended }\end{array}$ & Kegitan Pembelajaran & $\begin{array}{l}\text { High Order } \\
\text { Thinking Skills } \\
\text { (HOTS) }\end{array}$ & $\begin{array}{c}\text { Taksonomi } \\
\text { Bloom Revisi } \\
\text { Anderson \& } \\
\text { Krathwohl } \\
\text { (2001) }\end{array}$ & $\begin{array}{c}\text { Krulik \& } \\
\text { Rudnick } \\
(1999)\end{array}$ \\
\hline Orientasi & $\begin{array}{l}\text { Guru menyampaikan } \\
\text { tujuan yang ingin dicapai } \\
\text { dalam pembelajaran. } \\
\text { - Apersepsi } \\
\text { - Mengantarkan siswa } \\
\text { untuk mengingat } \\
\text { kembali pembelajaran } \\
\text { sebelumnya yang } \\
\text { masih terkait dengan } \\
\text { materi yang akan } \\
\text { dibahas }\end{array}$ & & & \\
\hline
\end{tabular}




\begin{tabular}{|c|c|c|c|c|}
\hline & 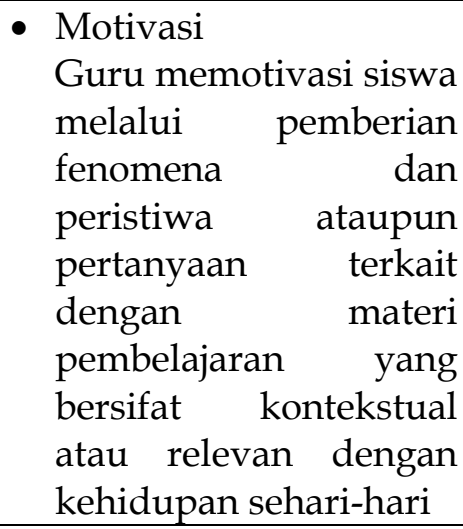 & & & \\
\hline $\begin{array}{l}\text { Penyajian } \\
\text { masalah }\end{array}$ & $\begin{array}{l}\text { - Guru menyajikan } \\
\text { permasalahan yang } \\
\text { bersifat terbuka } \\
\text { (openness) baik yang } \\
\text { berupa data, gambar } \\
\text { maupun fenomena } \\
\text { yang berkaitan dengan } \\
\text { materi. } \\
\text { - Siswa melakukan } \\
\text { observasi (mengamati) } \\
\text { terhadap permasalahan } \\
\text { yang diberikan melalui } \\
\text { proses pengajuan } \\
\text { pertanyaan-pertanyaan } \\
\text { dari permasalahan. }\end{array}$ & $\begin{array}{l}\text { Berpikir kritis } \\
\text { (critical thinking) } \\
\text { Siswa dituntut } \\
\text { untuk } \\
\text { mengembangkan } \\
\text { kemampuan } \\
\text { untuk mengkritisi } \\
\text { atau menganalisis } \\
\text { permasalahan }\end{array}$ & Menganalisis & $\begin{array}{l}\text { Critical } \\
\text { thinking }\end{array}$ \\
\hline $\begin{array}{l}\text { Pengerjaan } \\
\text { masalah } \\
\text { terbuka } \\
\text { secara } \\
\text { individu. }\end{array}$ & $\begin{array}{l}\text { - Guru mengarahkan } \\
\text { siswa untuk } \\
\text { memecahkan } \\
\text { permasalahan terbuka } \\
\text { secara individu. } \\
\text { - Siswa menganalisis, } \\
\text { mengidentifikasi dan } \\
\text { mengumpulkan } \\
\text { informasi baik melalui } \\
\text { penelusuran literatur } \\
\text { maupun rari dari } \\
\text { pengalaman yang } \\
\text { dimiliki r untuk } \\
\text { memecahkan } \\
\text { permasalahan. }\end{array}$ & $\begin{array}{l}\text { - Berpikir kritis } \\
\text { (critical } \\
\text { thinking) } \\
\text { Siswa dituntut } \\
\text { untuk } \\
\text { mengembangka } \\
\text { n kemampuan } \\
\text { untuk } \\
\text { mengkritisi dan } \\
\text { mengevaluasi } \\
\text { informasi- } \\
\text { informasi } \\
\text { sebagai bahan } \\
\text { pemecahan } \\
\text { masalah. } \\
\text { - Berpikir kreatif } \\
\text { dan pemecahan } \\
\text { masalah. } \\
\text { Siswa dituntut } \\
\text { untuk } \\
\text { menghasilkan } \\
\text { solusi atau } \\
\text { alternatif }\end{array}$ & $\begin{array}{l}\text { - Menganalisis } \\
\text { - Mengevaluasi } \\
\text { - Mencipta }\end{array}$ & $\begin{array}{l}\text { - Critical } \\
\text { thinking } \\
\text { - Creative } \\
\text { thinking }\end{array}$ \\
\hline
\end{tabular}




\begin{tabular}{|c|c|c|c|c|}
\hline & & $\begin{array}{l}\text { pemecahan } \\
\text { masalah. }\end{array}$ & & \\
\hline $\begin{array}{l}\text { Diskusi } \\
\text { kelompo } \\
\text { k tentang } \\
\text { masalah } \\
\text { terbuka. }\end{array}$ & $\begin{array}{l}\text { - Guru mengarahkan } \\
\text { siswa untuk } \\
\text { memecahkan } \\
\text { permasalahan terbuka } \\
\text { secara kelompok. dalam } \\
\text { - Siswa diskusi } \\
\text { kelompoknya } \\
\text { melakukan pemecahan } \\
\text { untuk mendapatkan } \\
\text { solusi dan } \\
\text { masalah melalui proses } \\
\text { menganalisis, } \\
\text { mengevaluasi dikiran. } \\
\text { saling bertukar pikiran }\end{array}$ & $\begin{array}{l}\text { - Berpikir kritis } \\
\text { (critical } \\
\text { thinking) } \\
\text { Siswa dituntut } \\
\text { untuk } \\
\text { mengembangka } \\
\text { n kemampuan } \\
\text { untuk } \\
\text { mengkritisi dan } \\
\text { mengevaluasi } \\
\text { berbagai } \\
\text { alternatif } \\
\text { pemecahan } \\
\text { masalah } \\
\text { - Berpikir kreatif } \\
\text { dan pemecahan } \\
\text { masalah. } \\
\text { Siswa dituntut } \\
\text { untuk } \\
\text { menghasilkan } \\
\text { solusi atau } \\
\text { alternatif } \\
\text { pemecahan } \\
\text { masalah yang } \\
\text { terbaik. } \\
\text { - Kemampuan } \\
\text { beragumen dan } \\
\text { pengambilan } \\
\text { keputusan } \\
\text { Siswa } \\
\text { mengembangka } \\
\text { n kemampuan } \\
\text { mengemukakan } \\
\text { ide-ide hingga } \\
\text { menghasilkan } \\
\text { suatu } \\
\text { keputusan } \\
\text { solusi. }\end{array}$ & $\begin{array}{l}\text { - Menganalisis } \\
\text { - Mengevaluasi } \\
\text { - Mencipta }\end{array}$ & $\begin{array}{l}\text { - Critical } \\
\text { thinking } \\
\text { - Creative } \\
\text { thinking }\end{array}$ \\
\hline $\begin{array}{l}\text { Persentas } \\
\text { i hasil } \\
\text { diskusi } \\
\text { kelompo } \\
\text { k }\end{array}$ & $\begin{array}{l}\text { - Guru menyuruh salah } \\
\text { satu kelompok untuk } \\
\text { membacakan hasil } \\
\text { diskusi kelompoknya } \\
\text { serta kelompok lain } \\
\text { menanggapi bila ada } \\
\text { jawaban berbeda. } \\
\text { - Siswa membacakan } \\
\text { hasil diskusi } \\
\text { kelompoknya dan }\end{array}$ & $\begin{array}{l}\text { - Kemampuan } \\
\text { beragumen } \\
\text { Siswa } \\
\text { mengembangka } \\
\text { n kemampuan } \\
\text { mengemukakan } \\
\text { ide-ide. }\end{array}$ & $\begin{array}{l}\text { - Menganalisis } \\
\text { - Mengevaluasi } \\
\text { - Mencipta }\end{array}$ & $\begin{array}{l}\text { - Critical } \\
\text { thinking } \\
\text { - Creative } \\
\text { thinking }\end{array}$ \\
\hline
\end{tabular}




\begin{tabular}{|l|l|l|l|l|}
\hline & $\begin{array}{l}\text { kelompok lain } \\
\text { menananggapi hasil } \\
\text { diskusi kelompok lain } \\
\text { bila ada jawaban yang } \\
\text { berbeda. }\end{array}$ & & & \\
\hline Penutup & $\begin{array}{l}\text { Guru melakukan } \\
\text { refleksi pembelajaran } \\
\text { (guru bersama siswa } \\
\text { menyimpulkan kembali } \\
\text { hasil pembelajaran). }\end{array}$ & & & \\
\hline
\end{tabular}

Dari tabel 2 dapat dilihat bahwa keterampilan berpikir tingkat tinggi terintegrasi pada setiap tahapan dalam pendekatan open-ended. Keterampilan berpikir tingkat tinggi mulai diarahkan pada tahap penyajian masalah. Permasalahan yang diajukan dapat berupa pertanyaan yang bersifat open-ended yang mana akan menghasilkan pola pikir divergen. guru dapat mengembangkan dan menggunakan 4 kata tanya yang dikemukakan oleh Krulick \& Rudnick (1993) (dalam Hidayati, 2017) yaitu: What's if ...? (Bagaimana jika ...?), What's wrong ... ? (Adakah yang salah ...?), what's would you do ....? (Apa yang akan kamu lakukan ...?) dan what's another ways ...? (Adakah cara lain ..? Disamping itu, guru juga dapat memberikan beberapa kata kerja operasional seperti menganalisis, mempertimbangkan, membandingkan, memeriksa, menilai, menafsirkan, menghubungkan dan menyimpulkan dengan mengkombinasikan kata tanya "adakah yang salah ..?”, “Adakah cara lain ...?”, “Apa yang akan kamu lakukan jika ...?” dan “ Bagaimana jika ..!". Melalui menyajikan masalah yang bersifat openness (terbuka) pada saat proses pembelajaran akan membuat para siswa terpacu untuk mengembangkan keterampilan berpikir yang bersifat kritis, kreatif atau imajinatif, dan logis dalam bentuk aktivitas menganalisis, mengevaluasi, dan menghasilkan alternatif solusi dalam pemecahan masalah. Melalui pendekatan open-ended siswa juga dilatih atau dipacau untuk mengembangkan kemampuan beragumen yang meliputi kemampuan mengembangkan dan mengemukakan atau menjelaskan ide-ide dan gagasan-gagasan hingga pada menyimpulkan jawaban atau penyelesaian suatu masalah

\section{Kesimpulan}


Pembelajaran dengan pendekatan open-ended dikembangkan mengacu pada proses keterampilan berpikir dengan level tinggi. Pendekatan open-ended merupakan pendekatan yang berbasis masalah atau pemecahan masalah secara terbuka yang mengkondisikan siswa untuk mengembangkan dan mengintegrasikan kemampuan berpikir pada tiap tahapannya mulai dari menganalisis masalah, mencari data, mengevaluasi, kemudian menyuguhkan alternatif (produk kreatif) sebegai bentuk dari kemampuan pengambilan keputusan (decision making). Siswa dirangsang mengembangkan kemampuan berpikir secara kritis, logis dan metakonitif, hingga kemampuan pengambilan keputusan. Dengan demikian pembelajaran dengan pendekatan open-ended mampu mengembangkan keterampilan berpikir tingkat tinggi siswa.

\section{Daftar Pustaka}

Anderson, L. W., \& Krathwohl, D. R. (2001). A Taxonomy For Learning, Teaching and Assessing. New York: Longman.

Ariandari, W. P. (2015). Mengintegrasikan Higher Order Thinking dalam Pembelajaran Creative Problem Solving. Seminar Nasional Matematika dan Pendidikan Matematika UNY, (pp. 489-496).

Ariani, I. M. D., Candiasa, I. M., \& Marhaeni, A. A. I. N. (2014). Pengaruh Implementasi Open-Ended Problem dalam Pembelajaran Matematika Terhadap Kemampuan Pemecahan Masalah dengan Pengendalian Kemampuan Penalaran Abstrak. eJournal Program Pascasarjana Universitas Pendidikan Ganesha, 4, pp.

Ariyana, Y., Pudjiastuti, A., Bestary, R., \& Zamroni. (2018). Buku Pegangan Pembelajaran Berorientasi pada Keterampilan Berpikir Tingkat Tinggi. Direktorat Jenderal Guru dan Tenaga Kependidikan Kementerian Pendidikan dan Kebudayaan.

Badjeger, R., \& Purwaningrum, J. P. (2018). Pengembangan Higher Order Thinking Skills dalam Pembelajaran Matematika di SMP. Guru Tua: Jurnal Pendidikan dan Pembelajaran, 1(1), 36-43.

Biliya A, B. (2015). Penerapan Model Open Ended untuk Meningkatkan Keterampilan Proses dan Hasil Belajar Siswa Kelas V SDN 1 Repaking-Wonosegoro-Boyolali. Scholaria, 5(1), 78-91.

Brookhart, S. M. (2010). How To Asses Higher Order Thinking Skills in Your Classroom. Alexandria: ASDC. 
Conklin, W., \& Manfro, J. (2010). Higher order Thinking Skills To Develop 21st Century Learners. Inc. Huntington: Shell Education Publishing.

Darmadi, H. (2011). Metode Penelitian Pendidikan. Bandung: Alfabeta.

Dinni, H. N. (2018). HOTS (High Order Thinking Skills) dan Kaitannya dengan Kemampuan Literasi Matematika. Prisma, Prosiding Seminar Nasional Matematika, 1, pp. 170-176.

Heong, Y. M., Othman, W. B., Yunos, J. B., Kiong, T. T., Hasan, R. B., \& Mohamad, M. B. (2011). The Level of Marzano Higher Order Thinking Skills. International Journal of Social Science and Humanity, 1(2), 121-125.

Hidayati, A. U. (2017). Melatih Keterampilan Berpikir Tingkat Tinggi dalam Pembelajaran Matematika pada Siswa Sekolah Dasar. Terampil: Jurnal Pendidikan dan Pembelajaran Dasar, 4(2), 143-156.

King, F. J., Goodson, L., \& Rohani, F. (2012). Higher Order Thinking Skills. Center for Advancement of Learning and Assessment.

Lahra, A. S., Hasan, M., \& Mursal. (2017). Pengembangan Modul Praktikum Berbasis Pendekatan Open Ended untuk Meningkatkan Kreativitas Siswa. Jurnal Pendidikan Sains Indonesia, 5(1), 36-43.

Lestari, N., Hartono, Y., \& Purwoko. (2016). Pengaruh Pendekatan Open-Ended Terhadap Penalaran Matematika Siswa Sekolah Menengah Pertama Palembang. Jurnal Pendidikan Matematika, 10(1), 81-94.

Meika, I., \& Sujana, A. (2017). Kemampuan Berpikir Kreatif dan Pemecahan Masalah Matematis Siswa SMA. JPPM, 10(2), 8-13.

Muhsinin, U. (2013). Pendekatan Open Ended pada Pembelajaran Matematika. Education Math Journal, 4(1), 46-59.

Sani, R. A. (2016). Penilaian Autentik. Jakarta: Bumi Aksara.

Saputra, H. (2016). Pengembangan Mutu Pendidikan Menuju Era Global: Penguatan Mutu Pembelajaran dengan Penerapan HOTS (HIgh Order Thinking Skills). Bandung: SMILE's Publishing.

Sari, A. N., Wahyuni, R., \& Rosmaiyadi. (2016). Penerapan Pendekatan Open-Ended untuk Meningkatkan Kemampuan Berpikir Kritis Siswa pada Materi Aljabar Kelas VIII SMP Negeri 10 Pemangkat. Jurnal Pendidikan Matematika Indonesia, 1(1), 20-24. 
Septiani, U., \& Zanthy, L. S. (2019). Pembelajaran Matematika Melalui Pendekatan OpenEnded Terhadap Pemahaman Matematik Siswa MTs. Jurnal Cendekia: Jurnal Pendidikan Matematika, 3(1), 28-33.

Soeyono , Y. (2014). Pengembangan Bahan Ajar Matematika dengan Pendekatan OpenEnded. PYTHAGORAS: Jurnal Pendidikan Matematika, 9(2), 205-218.

Supadmini, N. K., Wijaya, I. K. W. B, \& Larashanti, I. A. D. (2020). Implementasi Model Pendidikan Lingkungan UNESCO Di Sekolah Dasar. Cetta: Jurnal Ilmu Pendidikan, $3(1), 77-83$.

Suwandi, T., Hasnunidah, N., \& Marpaung, R. R. T. (2016). Pengaruh Pembelajaran Berbasis Masalah Open-Ended Terhadap Peningkatan Kemampuan Pemecahan Masalah Oleh Siswa. Jurnal Pendidikan Progresif, 6(2), 163-173.

Wijaya, I. K. W. B. (2020). Pengembangan Kompetensi 4C dan Keterampilan Proses Sains Melalui Pembelajaran Berbasis Catur Pramana. Guna Widya: Jurnal Pendidikan Hindu, 7(1), 70-76. 